\title{
Magnesium deficit - overlooked cause of low vitamin D status?
}

\author{
Armin Zittermann
}

\begin{abstract}
Like vitamin D deficit, magnesium deficit is considered to be a risk factor for cardiovascular disease. Several steps in the vitamin D metabolism, such as vitamin D binding to its transport protein and the conversion of vitamin D into the hormonal form 1,25-dihydroxyvitamin D by hepatic and renal hydroxylation, depend on magnesium as a cofactor. A new analysis of two National Health and Nutrition Examination Surveys data sets, published in BMC Medicine, investigated potential interactions between magnesium intake, circulating 25-hydroxyvitamin D, which is the generally accepted indicator of vitamin D status, and mortality. Data indicate a reduced risk of insufficient/deficient vitamin D status at high magnesium intake and an inverse association between circulating 25-hydroxyvitamin D and mortality, particularly cardiovascular mortality, among those with magnesium intake above the median. The study provides important findings concerning potential metabolic interactions between magnesium and vitamin D and its clinical relevance. However, results should be considered preliminary since biochemical data on individual magnesium status were lacking, confounding cannot be excluded and questions on the dose-response relationship still remain to be answered.

Please see related research article: http://www.biomedcentral.com/1741-7015/11/187.
\end{abstract}

Keywords: 25-hydroxyvitamin D, Cardiovascular mortality, Magnesium, Mortality, Vitamin D deficit

\section{Background}

Life depends on an energy-consuming complex interplay of organic and inorganic substances to maintain biological structures. Adequate energy and nutrient supply is a prerequisite to guarantee normal functioning of metabolic pathways and thus a healthy life. To become metabolically active, several nutrients require other essential nutrients as cofactors. For example, copper is required for the oxidation of absorbed $\mathrm{Fe}^{2+}$ to $\mathrm{Fe}^{3+}$, which is then bound to transferrin, and riboflavin (vitamin $B_{2}$ ) and pyridoxine (vitamin $\mathrm{B}_{6}$ ) are required to produce niacin (vitamin $\mathrm{B}_{3}$ ) from dietary tryptophan. Therefore, some nutrition-related illnesses, such as anemia and pellagra, can be caused by multiple nutrient deficits $[1,2]$. Magnesium $(\mathrm{Mg})$ is a cofactor that is required for the binding of vitamin D to its transport protein. Moreover, conversion of vitamin $\mathrm{D}$ by hepatic 25-hydroxlation and renal $1 \alpha$-hydroxylation into the active, hormonal form

\section{Correspondence: azittermann@hdz-nrw.de}

Clinic for Thoracic and Cardiovascular Surgery, Heart Center North RhineWestphalia, Ruhr-University of Bochum, Georgstraße 11, 32545, Bad Oeynhausen, Germany 1,25-dihydroxyvitamin $\mathrm{D}\left(1,25(\mathrm{OH})_{2} \mathrm{D}\right)$ is Mg-dependent $[3,4]$. A study by Deng et al. [5], published in BMC Medicine, investigated potential interactions between Mg intake, vitamin D status and mortality. Still, some questions remain open.

\section{Study results}

Deng et al. [5] used two large National Health and Nutrition Examination Surveys data sets to assess interactions between $\mathrm{Mg}$ intake, vitamin $\mathrm{D}$ status and outcome. According to the Institute of Medicine (IOM) classification, circulating 25-hydroxyvitamin D (25OHD), the generally accepted indicator of vitamin D status, was within the deficit range $(<12 \mathrm{ng} / \mathrm{ml})$ in $12 \%$ of participants and the insufficiency range (12 to $20 \mathrm{ng} / \mathrm{ml}$ ) [6] in 30\%. Mean energy-adjusted total $\mathrm{Mg}$ intake (dietary and supplemental) was clearly below the recommended daily allowance, which is between 310 and $420 \mathrm{mg}$ depending on age and gender [7]. High $\mathrm{Mg}$ intake was associated with reduced risk of vitamin D deficit or insufficiency. Data also indicate an inverse association between circulating 25OHD and

\section{Biomed Central}


mortality, particularly cardiovascular mortality, among those with $\mathrm{Mg}$ intake above the median.

\section{Vitamin D status and its predictors}

The present data are consistent with the assumption that deficient vitamin D levels are an important health issue that may affect not only musculoskeletal health but also a wide range of acute and chronic diseases [8]. The high prevalence of deficient 25OHD blood levels in the population is believed to be primarily due to inadequate vitamin D synthesis in the skin, together with inadequate dietary intake [9]. However, circulating 25OHD levels also depend on body weight and genetic factors, and a significant portion of the variance in circulating 25OHD remains unexplained at present. Therefore, Deng et al. are to be commended for investigating potential interactions between $\mathrm{Mg}$ and vitamin D status. Especially with regard to vitamin $\mathrm{D}$, there is still ongoing debate regarding the optimal oral intake and the adequate circulating 25OHD level. The IOM recommends a daily vitamin D intake of 600 international units and considers circulating $25 \mathrm{OHD}$ levels of 20 to $50 \mathrm{ng} / \mathrm{ml}$ as adequate, and $25 \mathrm{OHD}$ levels above $50 \mathrm{ng} / \mathrm{ml}$ as potentially harmful [6]. However, according to the Endocrine Society [10], the circulating 25OHD level should be within the range of 30 to $100 \mathrm{ng} / \mathrm{ml}$. To raise the $25 \mathrm{OHD}$ level consistently above $30 \mathrm{ng} / \mathrm{ml}$, they recommend a daily vitamin $\mathrm{D}$ intake of 1,500 to 2,000 international units.

\section{Open questions}

Like vitamin D deficit [11], Mg deficit is considered to be a risk factor for cardiovascular disease [12]. Thus, the presented interactions between $\mathrm{Mg}$, vitamin $\mathrm{D}$ and cardiovascular mortality fit well together. Nevertheless, for several reasons, data should be considered preliminary. First, associations are based on oral Mg intake. The assessment of oral Mg intake does not take into account inter-individual differences in intestinal $\mathrm{Mg}$ absorption and renal and cutaneous $\mathrm{Mg}$ loss. It would have been more appropriate to use biochemical data, such as plasma $\mathrm{Mg}$ levels (levels of 0.79 to $0.76 \mathrm{mmol} / \mathrm{l}$ have been classified as inadequate and levels $<0.76 \mathrm{mmol} / \mathrm{l}$ as deficient), to assess individual $\mathrm{Mg}$ status. Unfortunately, plasma levels of $\mathrm{Mg}$ are still rarely assessed, whereas measurement of circulating 25OHD levels has exploded in the clinical setting in recent years [13]. Second, total $\mathrm{Mg}$ intake, 25OHD status and physical activity level were clearly interrelated [5]. High $\mathrm{Mg}$ intake may thus only be an indicator for high physical activity, which is known to influence 25OHD status (and cardiovascular mortality). Even adjustment for physical activity may not completely solve the problem of potential bias. Third, no data on circulating levels of the biologically active form of vitamin $\mathrm{D}, 1,25(\mathrm{OH})_{2} \mathrm{D}$, were presented. Circulating
$1,25(\mathrm{OH})_{2} \mathrm{D}$ is probably a better predictor of total mortality compared with circulating $25 \mathrm{OHD}$, at least if midterm mortality is assessed [14]. Circulating $1,25(\mathrm{OH})_{2} \mathrm{D}$ declines significantly (and parathyroid hormone levels increase substantially) at $25 \mathrm{OHD}$ levels below $10 \mathrm{ng} / \mathrm{ml}$, whereas levels of both hormones seem to plateau at

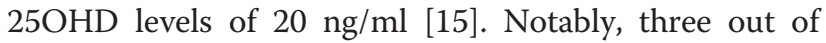
the four 25OHD categories in the mortality analysis of the present investigation were above $20 \mathrm{ng} / \mathrm{ml}$, and none covered the range that the IOM has classified as deficient. It would have been interesting to see whether the combination of inadequate $\mathrm{Mg}$ intake with 25OHD levels below $12 \mathrm{ng} / \mathrm{ml}$ is associated with a further mortality increase.

\section{Conclusion}

The present study must be praised for bringing potential interactions between individual nutrients into the focus of interest. Because the intake of $\mathrm{Mg}$ is often inadequate and several other factors are also known to impair Mg supply (for example, diuretics use, diabetes mellitus, chronic alcohol consumption, stress factors) [16-18], more attention should in future be paid to possible consequences of insufficient or deficient $\mathrm{Mg}$ supply in the general population. Further studies on the interactions between $\mathrm{Mg}$ supply and vitamin D status should include a more detailed assessment of individual Mg status (for example, by measuring biochemical parameters of $\mathrm{Mg}$ status or by adjusting statistical analysis for stress factors, diuretics use, alcohol consumption and concomitant diagnoses such as diabetes); a more detailed investigation of different components of the vitamin D-parathyroid hormone axis in general populations; clarification of the dose-response relationship; and the realization of randomized controlled trials to verify whether oral $\mathrm{Mg}$ is indeed able to improve vitamin D status and survival.

\section{Abbreviations}

1,25(OH) 2 D: 1,25-dihydroxyvitamin D; 25OHD: 25-hydroxyvitamin D; IOM: Institute of Medicine; Mg: Magnesium.

\section{Competing interests}

The author declares that he has received speaker honoraria from Abbott, Germany, and DiaSorin, Germany, two companies that provide test kits for the measurement of circulating 25-hydroxyvitamin D.

\section{Author information}

$A Z$ is a nutritionist, whose main research focuses on human vitamin D status, including the prevalence and consequences of vitamin D insufficiency or deficit. He is head of the study center at the Clinic for Thoracic and Cardiovascular Surgery at the Heart Center North-Rhine Westphalia, RuhrUniversity of Bochum, Germany.

Received: 28 August 2013 Accepted: 16 September 2013 Published: 24 Oct 2013

\section{References \\ 1. Karthikeyan K, Thappa DM: Pellagra and skin. Int J Dermato/ 2002, 41:476-481. \\ 2. Sharp P: The molecular basis of copper and iron interactions. Proc Nutr} Soc 2004, 63:563-569. 
3. Reddy V, Sivakumar B: Magnesium-dependent vitamin-D-resistant rickets. Lancet 1974, 1:963-965.

4. Rude RK, Adams JS, Ryzen E, Endres DB, Niimi H, Horst RL, Haddad JG Jr, Singer FR: Low serum concentrations of 1,25-dihydroxyvitamin D in human magnesium deficiency. J Clin Endocrinol Metab 1985, 61:933-940.

5. Deng X, Song Y, Manson JE, Signorello LB, Zhang SM, Shrubsole M, Ness RM, Seidner D, Dai Q: Magnesium, vitamin D status and mortality: results from US National Health and Nutrition Examination Survey (NHANES) 2001 to 2006 and NHANES III. BMC Med 2013, 11:187.

6. Ross AC, Manson JE, Abrams SA, Aloia JF, Brannon PM, Clinton SK, DurazoArvizu RA, Gallagher JC, Gallo RL, Jones G, Kovacs CS, Mayne ST, Rosen CJ, Shapses SA: The 2011 report on dietary reference intakes for calcium and vitamin $D$ from the Institute of Medicine: what clinicians need to know. J Clin Endocrinol Metab 2011, 96:53-58.

7. Standing Committee on the Scientific Evaluation of Dietary Reference Intakes, Food and Nutrition Board, Institute of Medicine: Dietary reference intakes for calcium, phosphorus, magnesium, vitamin D, and fluoride. Washington D.C: National Academy Press; 1997.

8. Hossein-nezhad A, Holick MF: Optimize dietary intake of vitamin D: an epigenetic perspective. Curr Opin Clin Nutr Metab Care 2012, 15:567-579.

9. Tsiaras WG, Weinstock MA: Factors influencing vitamin D status. Acta Derm Venereol 2011, 91:115-124.

10. Holick MF, Binkley NC, Bischoff-Ferrari HA, Gordon CM, Hanley DA, Heaney RP, Murad MH, Weaver CM, Endocrine Society: Evaluation, treatment, and prevention of vitamin D deficiency: an Endocrine Society clinical practice guideline. J Clin Endocrinol Metab 2011, 96:1911-1930.

11. Pilz S, Kienreich K, Tomaschitz A, Lerchbaum E, Meinitzer A, März W, Zittermann A, Dekker JM: Vitamin D and cardiovascular disease: update and outlook. Scand J Clin Lab Invest Suppl 2012, 243:83-91.

12. Seelig M: Cardiovascular consequences of magnesium deficiency and loss: pathogenesis, prevalence and manifestations-magnesium and chloride loss in refractory potassium repletion. Am J Cardiol 1989, 63:4G-21G.

13. Shahangian S, Alspach TD, Astles JR, Yesupriya A, Dettwyler WK: Trends in laboratory test volumes for Medicare part B reimbursements, 2000-2010. Arch Pathol Lab Med 2013 [Epub ahead of print].

14. Zittermann A, Schleithoff SS, Frisch S, Götting C, Kuhn J, Koertke H, Kleesiek K, Tenderich G, Koerfer R: Circulating calcitriol concentrations and total mortality. Clin Chem 2009, 55:1163-70.

15. Zittermann A: Vitamin $D$, and disease prevention with special reference to cardiovascular disease. Prog Biophys Mol Biol 2006, 92:39-48.

16. Abbott L, Nadler J, Rude RK: Magnesium deficiency in alcoholism: possible contribution to osteoporosis and cardiovascular disease in alcoholics. Alcohol Clin Exp Res 1994, 18:1076-1082.

17. Barbagallo $M$, Belvedere $M$, Dominguez LJ: Magnesium homeostasis and aging. Magnes Res 2009, 22:235-246.

18. Weber KT, Bhattacharya SK, Newman KP, Soberman JE, Ramanathan KB, McGee JE, Malik KU, Hickerson WL: Stressor states and the cation crossroads. J Am Coll Nutr 2010, 29:563-574.

10.1186/1741-7015-11-229

Cite this article as: Zittermann: Magnesium deficit - overlooked cause of low vitamin D status?. BMC Medicine 2013, 11:229

\section{Submit your next manuscript to BioMed Central and take full advantage of:}

- Convenient online submission

- Thorough peer review

- No space constraints or color figure charges

- Immediate publication on acceptance

- Inclusion in PubMed, CAS, Scopus and Google Scholar

- Research which is freely available for redistribution

Submit your manuscript at www.biomedcentral.com/submit 